\title{
Pain, prejudice, and prohibition
}

\section{The history of opioid drug policy in Canada}

\author{
Cindy Zhu, Asma Amir Ali \\ Faculty Reviewer: Shelley McKellar, PhD (Department of History; Department of Surgery)
}

\section{INTRODUCTION}

Historically, the use of drugs has been a part of every society, consumed for ritual or religious purposes, for pleasure, to enhance performance, or as a means to cure ailments or relieve symptoms. In the 20th century, a distinction has arisen between legal drugs which are prescribed and administered by medical professionals, and illegal drugs which are subject to state regulation and suppression. In particular, opium derivatives and related semisynthetic and synthetic compounds including morphine, heroin, codeine, hydrocodone, oxycodone, and methadone have been subject to numerous restrictions in prescription, possession, and distribution internationally. The history of opioid regulations in Canada and the criminalization of its use is a story of complex socioeconomic and cultural factors, navigating the elements of otherness and threat associated with the opioid drug user, from the Chinese opium den to the criminal addict. As stakeholders in this discussion, physicians have been both the regulators and the regulated with respect to the availability and accessibility of opioids. An examination of this history can be instructive in reflecting on our approach to drug policy today.

\section{HISTORICAL USE OF OPIATES}

Sir William Osler feted it as "God's own medicine," and indeed opium has been one of the most widely used and extolled drugs throughout history. Derived from juices of the poppy plant harvested in central Asia, opium has been used as early as $3100 \mathrm{BC}$ for its potent anesthetic and euphoric effects. The drug was well known in ancient Greece, introduced to China by Arab traders by the 10th century AD, and spread onwards to all parts of Europe. ${ }^{1}$ In the 16th century, the number of medical recipes using opium began to increase, with Paracelsus creating a tincture for which he coined the word "laudanum."1 Laudanum, which came to mean a solution of opium in alcohol, was widely prescribed by physicians for any number of illnesses including pain, sleeplessness, diarrhea, convulsions, delirium, and nervous disorders. ${ }^{1}$ With the widespread use of opiates, the problems of dependence and addiction too became known. The 17th century English physician Thomas Willis warned against the "dazzlingly seductive Opium" which could bring "destructive Tragedies" with an excessive or unreasonable dose. ${ }^{1}$ The largest burden of addiction was in China, with widespread use despite a ban by imperial edict due to an influx of opium trafficked by the British East India Company; this triggered the First (1839-1842) and Second Opium Wars (1856-1860). ${ }^{2}$

\section{EARLY LEGISLATION: THE RACIALIZATION OF OPIUM AND THE NARCOTICS DIVISION}

Morphine was purified from opium in 1804, and greatly utilized in the American Civil War (1861-1865); ${ }^{2}$ heroin was synthesized in 1874. ${ }^{1}$ Their addictive potential was recognized and documented, but addiction was regarded as an unfortunate consequence and not a threat to society at large; consumption of medicinal opioids was not uncommon as Canadians could purchase them readily at the local pharmacy. In contrast, opium smoking was closely identified with the Chinese immigrants who started arriving during the $1850 \mathrm{~s}$ to build the Canadian Pacific Railway. Public anti-Chinese sentiment led the government to impose a $\$ 50$ head tax on all Chinese immigrants, which was raised to $\$ 500$ by $1904 .{ }^{3}$ Events culminated with a rally in Vancouver in September 1907, which exploded into violence and vandalism as the rioting mob of thousands destroyed numerous Chinatown properties. ${ }^{4}$ Deputy Minister of Labour William Lyon Mackenzie King was charged with the on-site investigation; appalled by circulating reports that opium smoking was seducing and corrupting young Caucasian women of good social standing, he drafted the "Report on the Need for the Suppression of Opium Traffic in Canada." 4 Within a month of its release, Canada passed federal legislation prohibiting the importation, sale, and manufacture of opium for nonmedical purposes.

Opium use and possession became criminalized under the Opium and Drug Act of 1911. Subsequent amendments reduced the legitimate scope of medical opium, increased penalties to include significant jail time, increased police powers of search and seizure, and added cocaine and marijuana. ${ }^{5}$ The image of the nefarious Chinese drug menace was further promoted to the Canadian public by magistrate Emily Murphy in a series of articles in Maclean's magazine and in her 1922 book The Black Candle. ${ }^{4}$ Drug use and addiction was seen as a contagion, and users as both victims of injury to the self, and criminals in causing injury to others. ${ }^{5}$ The new legislations were implemented through the creation of the Narcotics Division, while the professional autonomy of physicians to prescribe and administer opioids became severely restricted. Law enforcement was positioned as the highest authority on the legitimate and illegitimate uses of opioids, and what constituted sound medical practice. The narcotics purchases of physicians were scrutinized through the newly introduced licensing system. Additionally, the classification of drug users as criminal addicts was used to delegitimize the few physicians who called for the extension of treatment beyond arrest and confinement. ${ }^{5}$ 


\section{GLOBAL INFLUENCES: THE VIETNAM WAR \& INTERNATIONAL TREATIES}

Canadian opioid regulations changed little in the subsequent decades. By the 1930s, there were few Chinese drug users left due to deportations and the restriction of immigration by the Chinese Immigration Act of 1923. ${ }^{4}$ For Caucasian drug users, criminalization and harsher penalties made opioid use an increasingly dangerous activity. The poor economic conditions of the Great Depression and the shortage of anesthetics during World War II made it difficult for users to obtain opioids. ${ }^{4}$ In addition, opioid production and trade were being increasingly regulated by international treaties. The landmark charter was the 1961 United Nations Single Convention on Narcotic Drugs, which created 4 schedules of controlled substances and a process for additions to keep pace with accelerating advances in chemistry without the need to ratify amendments. ${ }^{6}$ Stating that "addiction to narcotic drugs constitutes a serious evil for the individual [...] fraught with social and economic danger to mankind," the goal was the global prohibition of all nonmedical and nonscientific use of narcotic drugs, a category under which cannabis was included for the first time in international regulations. ${ }^{6} \mathrm{By}$ signing this treaty, Canada took on an international responsibility to prohibit narcotic production, possession, distribution, and consumption.

The Vietnam War (1963-1975) began just as the convention was adopted. Military conflict and substance use have always had a synergistic relationship, with drugs used to relieve the pain of war and stimulate troops to fight. At the height of the Vietnam War, heroin produced in the Golden Triangle of Southeast Asia became widely available amongst the troops in Vietnam and civilians in America. ${ }^{2}$ In 1971, President Richard Nixon declared drug abuse "public enemy number one." Drug use became framed administratively and socially as a threat to national security, with the response phrase "War on Drugs" equally militaristic. The legacy of Nixon's Drug Enforcement Administration has been one which further entangled war and drugs, as American covert operations entwined with Afghan and Pakistani drug traffickers during the Soviet-Afghan war (19791989); Afghanistan, Iran, and Pakistan became opium's new empire, the Golden Crescent. ${ }^{2}$ The billions of dollars generated by the illicit narcotics trade continue to contribute to international civil and political unrest, and thereby to the perpetuation of the prohibitionist approach to opioid drug regulations.

\section{THE MEDICALIZATION OF OPIOID USE: TOWARDS HARM REDUCTION}

The treatment-based paradigm for drug abuse emerged in the 1950s, as medicine became a more powerful and prestigious profession than ever before. The quality of medical care had improved significantly with the development of germ theory, antisepsis, and antibiotics. It seemed reasonable that the ability of modern medical practice to heal could extend to include drug addiction. Of particular significance was the report penned by Dr Lawrence Ranta, chair of an independent committee appointed by the Community Chest and Council of Greater Vancouver (a forerunner to the United Way). The report made only 2 recommendations, yet fundamentally challenged Canadian approaches to illicit drug use at the time. The first called for a pilot medical treatment and rehabilitation centre for drug users. The second advocated for provincial narcotics clinics where users could receive maintenance doses. ${ }^{5}$ In 1958, the first methadone program in Canada opened in Vancouver, initially for the treatment of withdrawal symptoms from morphine or heroin and later for maintenance. ${ }^{4}$ In 1961, the Narcotic Control Act granted physicians more professional autonomy, as the regulation of prescription practices shifted from the purview of law enforcement to provincial licensing bodies. ${ }^{5}$

In 1969, the Commission of Inquiry into the Non-Medical Use of Drugs, better known as the Le Dain Commission, was established to gather data and to make recommendations to the federal government on the phenomenon of nonmedical drug use, particularly of cannabis. ${ }^{7}$ In describing and analyzing the social and individual costs of the criminalization legislation, the Commission was an important step in the development of a policy of harm reduction in Canada; the report recommended a gradual withdrawal from criminal sanctions. ${ }^{8}$ The harm reduction approach has since been repeatedly validated for its safety, efficacy, and cost-effectiveness. ${ }^{9}$ The human immunodeficiency virus (HIV) epidemic of the 1980s and the rise of infection among injection drug users, mainly of heroin, prompted the expansion of harm reduction efforts. The first syringe exchange program started in Toronto in 1988, with many following in communities across Canada. ${ }^{10}$ Despite numerous efforts aimed at decriminalization, the current federal drug legislation, the Controlled Drugs and Substances Act enacted in 1994, remains soundly prohibitionist. ${ }^{11}$ The National Anti-Drug Strategy implemented by the Harper conservative government in 2008 further emphasized the criminal nature of drug use, with $70 \%$ of funding allocated to law enforcement and only $17 \%$ to treatment programs. ${ }^{12}$

\section{CONCLUSION}

While physicians have been leaders in advocacy for harm reduction and decriminalization, the role of physicians in the prescription opioid addiction epidemic must also be acknowledged. Nonmedical use of prescribed opioids is now the 4th most prevalent form of substance use in Canada, behind alcohol, tobacco, and cannabis. ${ }^{13}$ In Ontario, the number of fatal opioid overdoses has increased $242 \%$ between 1991-2010, to approximately 550 deaths each year. ${ }^{14}$ With the blurring line between licit and illicit opioid drug use, and the role of physicians as gatekeepers, an understanding of the history and context of opioid drug regulations is increasingly important. As part of a strategy to combat this crisis, some have proposed establishing prescription monitoring programs and increasing physician adherence to prescribing and dispensing guidelines; ${ }^{15}$ it is not difficult to recall similar regulations on physician actions pre-1961. Simultaneously, it is a time of great potential. Physicians can play a major role in shaping the development of legislation to reduce barriers to effective opioid addiction treatment and prevent the harms of opioid use. 


\section{REFERENCES}

1. Davenport-Hines R. The pursuit of oblivion: a global history of narcotics. New York, NY: Norton \& Company; 2002.

2. Bergen-Cico DK. War and Drugs: The role of military conflict in the development of substance abuse. Boulder, CO: Paradigm Publishers; 2012.

3. Calgary Chinese Cultural Centre. A history of exclusion [Internet]. Calgary, AB: Calgary Chinese Cultural Centre; 2008 [cited 2015 Dec]. Available from: http://www.culturalcentre.ca/chinese_albertan_history/policies.htm

4. Carstairs C. Jailed for possession: illegal drug use, regulation, and power in Canada, 1920-1961. Toronto, ON; University of Toronto Press; 2006.

5. Grayson K. Chasing dragons: security, identity, and illicit drugs in Canada. Toronto, ON: University of Toronto Press; 2008.

6. United Nations. Single Convention on Narcotic Drugs, 1961, as amended by the 1972 Protocol [Internet]. Vienna, Austria: International Narcotics Control Board; 1972 [cited 2015 Dec]. Available from: http:// www.incb.org/documents/Narcotic-Drugs/1961-Convention/convention_1961_en.pdf

7. Martel M. Not this time: Canadians, public policy, and the marijuana question 1961-1975. Toronto, ON: University of Toronto Press; 2006.

8. The report of the Canadian Government Commission of Inquiry into the Non-Medical Use of Drugs [Internet]. Ottawa, ON: Schaffer Online Library of Drug Policy; c2006. Conclusions and Recommendations; c2006 [cited 2015 Dec]. Available from: http://www.druglibrary.org/ schaffer/library/studies/ledain/ldctoc.html

9. Ritter A, Cameron J. A review of the efficacy and effectiveness of harm reduction strategies for alcohol, tobacco and illicit drugs. Drug Alcohol Rev. 2006 Nov;25(6):611-24.

10. Weekes J, Palmer D. Needle exchange programs (NEPs) [Internet]. Ottawa, ON: Canadian Centre on Substance Abuse; 2004 [cited 2015 Dec]. Available from: http://www.ccsa.ca/Resource\%20Library/ccsa010055-2004.pdf

11. Minister of Justice. Controlled drugs and substances act [Internet]. Ottawa, ON: Minister of Justice; 2015 [cited 2015 Dec]. Available from: http://laws-lois.justice.gc.ca/PDF/C-38.8.pdf

12. Debeck K, Wood E, Montaner J, Kerr T. Canada's new federal 'National Anti-Drug Strategy': an informal audit of reported funding allocation. Int J Drug Policy. 2009 Mar;20(2):188-191.

13. Fischer B, Argento E. Prescription Opioid related misuse, harms, diversion and interventions in Canada: a review. Pain Physician. 2012 Jul;15(3 Suppl):ES191-203.

14. Carter CI, Graham B. Opioid overdose prevention \& response in Canada [Internet]. Vancouver, BC: Canadian Drug Policy Coalition; 2013 [cited 2015 Dec]. Available from: http://drugpolicy.ca/wp-content/uploads/2014/07/CDPC_OverdosePreventionPolicy_Final_July2014.pdf

15. National Advisory Council on Prescription Drug Misuse. First, do no harm: responding to Canada's prescription drug crisis [Internet]. Ottawa, ON: National Advisory Council on Prescription Drug Misuse; 2013 [cited 2015 Dec]. Available from: http://www.ccsa.ca/resource\%20 library/canada-strategy-prescription-drug-misuse-report-en.pdf 